ПАНЧЕНКО С. В., Д-р техн. наук, професор,

КАРГІН А. О., д-р техн. наук, професор,

ПЕТРЕНКО Т. Г., к-т. техн. наук, доцент (Український державний університет залізничного транспорту)

\title{
Науково-навчальний полігон IT-Industry 4.0: стратегічні завдання підготовки ІT-спеціалістів для галузі залізничного транспорту
}

Одним із головних питань, щзо пов'язані з індустріальною револючією 4.0, є підготовка фахівців нової генерації з інформаційних технологій. Галузь залізничного транспорту є одним із лідерів впровадження концепцій Industry 4.0. В планах стратегічного розвитку залізничної галузі розвинених краӥн світу передбачається широке застосування інформаційних технологій, щуо засновані на моделях штучного інтелекту, для створення індустріального «Інтернету речей», розумних машин та інших високоінтелектуальних систем. Розробка та обслуговування систем такого класу потребує IT-фахівців. Шляхам вирішення проблеми підготовки ІT-фахівців для залізничної галузі, які затребувані Industry 4.0, присвячена стаття.

Ключові слова: Industry 4.0, розумні машини, «Інтернет речей», інтелектуальні інформаційні технології, підготовка фахівичів.

\begin{abstract}
Вступ
Сьогодні наукова спільнота та бізнес широко обговорюють питання, пов'язані 3 індустріальною революцією 4.0 (Industry 4.0). На Всесвітньому економічному форумі в Давосі в 2017 році тема четвертої промислової революції була однією 3 головних і їй були присвячені 27 засідань [1]. 3 четвертою цифровою революцією пов'язують масове впровадження кіберфізичних систем у виробництво. Ці системи будуть об'єднуватися в одну мережу, щоб мати можливість обмінюватися інформацією i знаннями один $з$ одним в режимі реального часу на основі технології міжмашинної взаємодії (Machine-toMachine, M2M) [2-6]. Доступ до Internet отримують не тільки обчислювальні пристрої типу комп'ютерів і мобільних телефонів, а й автомобілі, фотоапарати, пральні машини, холодильники, медичні датчики, наручні електронні годинники i багато інших побутових та промислових машин. Над проектами «розумне місто» (Smart City, SC), як ознаками Industry 4.0, вже протягом ряду років працюють у багатьох країнах. Про масштаби можна судити за КНР. В даний час проекти SC реалізуються у 290 містах і планується розширення цього досвіду на 500 міст до кінця 2017 р. [7].
\end{abstract}

Індустріальна революція 4.0 - це цифрова революція в усіх сферах діяльності людини: від побуту та дозвілля до виробництва. Вона охоплює всі етапи виробництва: автономна робота «розумних заводів» (Smart Plants, SP), «розумних машин» (Smart Machine, $\mathrm{SM})$; інтеграція за допомогою мережних технологій

(C) С. В. Панченко, А. О. Каргін, Т. Г. Петренко, 2017 великих даних в хмарних сховищах 3 метою їх інтелектуальної обробки для більш ефективного виробництва. Industry 4.0 нерозривно пов'язують не тільки 3 новою електронною базою, інтелектуальними сенсорними системами і актуаторами, але і 3 новими інформаційними технологіями, які засновані на моделях штучного інтелекту. У статті розглядаються питання, пов'язані 3 дослідженнями та підготовкою фахівців 3 інформаційних технології, що будуть мати попит Industry 4.0.

\section{Аналіз досліджень та публікацій}

У доповіді [8] про стан інформатизації та розвитку інформаційного суспільства в Україні за 2013 рік виділено чотири основні тенденції: соціальні мережі, мобільні пристрої, хмарні технології i управління інформацією. Відзначається, що об'єднання цих технологій істотно змінить бізнес i суспільство, зруйнує старі бізнес-моделі і створить нових лідерів IT-ринку [9]. Відповідно до цих тенденцій очікується зростання впливу мобільних технологій і створення нового покоління мобільних обчислень; персоналізація хмарних сервісів і перетворення їх в центральний інструмент для користувачів; об'єднання даних i програм управління пристроями за допомогою Internet; поява сервісів для користувачів і для корпоративного ринку «Інтернет речей» (Internet of Things, IoT); злиття концепцій IoT i BigData, що дозволить обробляти великий обсяг неструктурованої інформації і аналізувати іiі у реальному часі.

Галузь залізничного транспорту є одним з лідерів у світі за впровадженням систем та технологій Industry 4.0 [10] . Проілюструємо це даними з плану реалізації 
стратегічного розвитку залізничної галузі Великобританії (Rail Technical Strategy Capability Delivery Plan) [11], розрахованого на 30 років. У Великобританії існує питома вага пасажирських та вантажних перевезень залізничним транспортом i розвитку цієї галузі приділяється особлива увага. У плані реалізації стратегії, затвердженої на державному рівні у 2012 році, передбачено дванадцять ключових напрямків. Це:

1. Зменшення інтервалу між поӥздами, де передбачається не просто зменшення інтервалу руху між суміжними поїздами, а й концептуальні зміни, які включають динамічне переформування поїздів, що вимагає розробки інтелектуальних систем автоводіння поїздів 3 використанням локальної та глобальної сенсорної інформації щодо станів поїздів та інфраструктури.

2. Мінімальні збої руху поӥзів, що передбачає контроль стану працездатності в режимі реального часу за допомогою безлічі інтелектуальних вбудованих датчиків, які пов'язані один 3 одним в IоT. Аерокосмічні SM надають додаткову візуальну i географічну інформацію про інфраструктуру і рухомий склад. Інтелектуальна розвідка в реальному часі, використовуючи машинне навчання і велику аналітику даних, формує плани профілактичного обслуговування.

3. Ефективний пасажиропотік через станиії, де поїзди розглядаються з позицій $\mathrm{SC}$, в якому залізниця $\epsilon$ частиною інтелектуальних і інтегрованих рішень для мобільності. При цьому вирішуються завдання автоматичного спрямування пасажира на найближчу доступну парковку, пропонуються транспортні рішення для подальшої подорожі пасажирів, виконується масштабування варіантів транспортування відповідно до прогнозованого попиту. Використання електронних квитків і біометричних систем на основі мобільних додатків знімає проблему «вузьких місць» і забезпечує інтелектуальне управління потоками пасажирів (особливо на великих вузлових станціях).

4. Більше значимої інформації з даних передбачає створення галузевої інформаційної архітектури та структури управління інформацією 3 метою координації інформаційних потреб i захисту інформації.

5. Оптимальне використання енергї: крім технічних завдань отримання і перетворення енергії, планується створення інтелектуальної системи управління транспортуванням енергії всередині системи відповідно до пропонування і попиту.

6. Більше місия в поїздах забезпечується здатністю швидко і легко переналаштовувати внутрішню частину пасажирських поїздів, як при нормальній щоденній експлуатації, так і в особливих ситуаціях.

7. Обслуговування точно в секунду має за мету поліпшення ситуаційної обізнаності, підвищення операційної гнучкості і забезпечення більш швидкого відновлення від збоїв за рахунок знання місця розташування і швидкості поїздів в реальному часі.

8. Інтелектуальні поӥзд - мережа повністю автономних інтелектуальних поїздів буде саморегулюватися, поїзди здатні вести переговори класу М2М для узгодження руху i розв'язання потенційних конфліктів. Це потребує концептуальних змін в управлінні рухом поїздів - передача сигналів поїзда буде перенесена 3 інфраструктури в поїзди 3 використанням нових технологій.

9. Персоналізована робота з клієнтами передбачає доступ до залізниці на основі електронного квитка; пасажири автоматично ідентифікуються і з їх рахунків стягуються відповідні збори за проїзд; методами машинного навчання формуються характеристики пасажирських поїздок і надаються в режимі реального часу, як рекомендації, щоб поліпшити подорож, виходячи із розуміння переваг пасажирів.

10. Гнучкі вантажоперевезення, де передбачається, що залізниця може повністю інтегруватися 3 інтермодальними вантажними i сервісними послугами на нових ринках для легких товарів високої вартості; вантажні перевезення будуть володіти гнучкістю для збільшення різноманітності вантажів i максимального використання вагонів; модальні обміни будуть автоматизовані, дозволяючи швидко i ефективно передавати вантажі для подальшого транзиту.

11. Недорогі залізничні рішення забезпечуються проектуванням, побудовою та експлуатацією залізничних ліній і поїздів 3 використанням сучасних матеріалів і технологічних рішень.

12. Прискорене дослідження, розробка $i$ впровадження технологій реалізується інвестиціями в наукові проекти і їх тестування.

Концептуальною основою вирішення більшості 3 перерахованих вище напрямків є розумні системи типу SP, SM і IоT, створення яких неможливо без нових інтелектуальних інформаційних технологій. 3 метою відповідності профільних університетів залізничної галузі викликам індустріальної революції 4.0 потрібен перегляд як наукових проектів, які виконуються університетами, так і інженерних освітніх програм, створення нової науково-дослідної та навчальної лабораторної бази, підготовка ІТ-фахівців, які будуть затребувані Industry 4.0. У документах [8,9,12-14] відзначається кадрова проблема, 3 якою сьогодні зіткнулася IT-індустрія України: брак кадрів і неповна відповідність рівня знань випускників вишів вимогам галузей, які інвестують кошти в Industry 4.0. Серед причин відзначається недостатній рівень підготовки 3 інформатики у школярів, слабке оновлення навчальних планів університетської освіти, недосконалість сучасних механізмів підвищення кваліфікації викладачів вищих навчальних закладів i, однією 3 
І Н Ф О Р М А Ц Й Н О - КЕ Р У Ю Ч І С И С ТЕ МИ Н А З А Л І З Н ИЧ Н О М У Т Р А Н С П О Р Т І

головних причин, називають відносно низькі посадові оклади в сфері IT-освіти в порівнянні $з$ окладами ITфахівців у бізнесі.

Перші важливі кроки в подоланні названих проблем зроблені. У школах США, Англії та інших країн дітей вчать використовувати мікробібліотеки, одноплатні комп'ютери 3 безпровідним зв'язком, сенсорами i програмованими кнопками, технології роботи $з$ платформами IоТ з відкритим кодом [15]. В Україні в 2016 році компанією «Майкрософт Україна» презентовано проект «Школа SMART» [16], головна мета якого - навчати школярів концепції IoT. У проекті беруть участь 10 навчальних закладів. Реалізація проекту спрямована на обчислювальні можливості мікроконтролера Arduino і мікропроцесора Raspberry Pi на основі хмарної платформи Microsoft Azure IoT Suite.

У бакалаврських та магістерських освітніх програмах по IoT університети ураховують рекомендації щорічних звітів NMC Horizon Report Higher Education Edition. Останніми роками в них значне місце відводиться обговоренню освітніх програм, націлених на підготовку фахівців, затребуваних новими виробничими галузями, які породжуються Industry 4.0. В останньому звіті 2017 року [17] відзначається, що збільшення попиту на кваліфікованих фахівців у таких галузях як інженерна техніка, розробка датчиків, проектування і інтеграція систем зумовило перехід до підготовки студентів за новими дисциплінами та програмами. Рекомендації експертів, думки яких узагальнені в звіті, сформульовані у вигляді шести основних напрямків навчання студентів, які зможуть задовольнити майбутні потреби в робочій силі. Три 3 шести напрямків мають безпосереднє відношення до Industry 4.0. Це IoT, Learning Management systems (LMS) i Artificial Intelligence (AI). Спільними рекомендаціями $\epsilon$ те, що програми повинні бути міждисциплінарними і комплексними [17].

\footnotetext{
Модель підготовки фахівців 3 інформаційних технологій, що відповідає вимогам Industry 4.0

Український державний університет залізничного транспорту (УкрдУЗТ, http://www.kart.edu.ua) відповідно до міждисциплінарного i комплексного підходу та рекомендацій NMC на базі новоствореної кафедри інформаційних технологій розпочав підготовку бакалаврів, магістрів і докторів філософії за освітніми програмами «Технології штучного інтелекту» на базі спеціальності 126 «Інформаційні системи та технології», «нтелектуальні інформаційні технології» на базі спеціальності 123 «Комп'ютерна інженерія» та «Інтелектуальні машини» на базі спеціальності 151 «Автоматизація та комп'ютерноінтегровані технології».
}

Навчання студентів нових інформаційних технологій вимагає переосмислення традиційної концепції підготовки. Наведемо декілька фактів на підтвердження сказаного. По-перше, математична підготовка повинна бути зосереджена на моделі штучного інтелекту (інженерія знань, обчислювальний інтелект, когнітивні науки, моделі, запозичені у живої природи), оскільки технології АІ стають лідируючими в Industry 4.0. По-друге, у SM, IoT та інших концепціях, про які йшла мова у зв'язку з Industry 4.0, стирається грань між апаратним та програмним забезпеченням. Розробити ІоТ-систему неможливо без глибокого розуміння завдань суміжних спеціалізацій традиційного програмування (C/C++, C\#, Python), програмування web-додатків, систем зв'язку й мережних технологій, архітектури мікроконтролерів та мікропроцесорів i їх програмування, системного програмування та системного програмного забезпечення (ПЗ), схемотехніки, фізичних основ автоматизованих процесів та сучасних технологій й інструментальних середовищ розробки ПЗ. Тому IT стає міждисциплінарною наукою. ІТ-фахівець нового покоління повинен знати і мати навички 3 декількох суміжних галузей знань і навчальний план програми підготовки такого фахівця повинен бути міждисциплінарним.

Переосмисленню підлягають, в першу чергу, існуючі пріоритети на молодших курсах між фундаментальною математичною підготовкою і IT. Викладання концепцій IоT першокурсникам непросте завдання: студенти не готові до програмування додатків для мереж i датчиків. Більшість запропонованих інструментів розробки вимагають знань у галузі апаратного забезпечення, чого у студентів першого курсу немає. Крім цього студенти перевантажені фундаментальними дисциплінами i не мають додаткового аудиторного часу для роботи з наставниками. В освітніх програмах, які пропонує УкрДУЗТ, зроблена спроба вирішити цю проблему. На першому курсі на базі чотирьох дисциплін - «Алгоритмізація та програмування», «Введення до IT», «Фізика» та «Вища математика»студенти повинні набути навичок розробки навчальної IoT: опитування датчика, що вимірює фізичний параметр, попередня обробка й передача даних по безпровідній мережі та зберігання цих даних в хмарній структурі. Студент набуває навичок роботи мовою Python, програмування мікроконтролера ESP 3 використанням бібліотек, інтеграції окремих апаратних засобів (датчик, мікроконтролер, модулі безпровідного зв'язку). На старших курсах розробка навчального проекту триває й удосконалюється по мірі освоєння блоків дисциплін, присвячених поглибленому програмуванню, архітектури систем і мереж, обчислювальної математики, штучного інтелекту та ін. Випускні бакалаврські та магістерські 
І Н Ф О Р М А Ц Й Н О - КЕ Р У Ю Ч І С И С Т Е М И Н А З А Л І З Н И Ч Н О М У Т Р А Н С П О Р Т І

роботи $\epsilon$ завершальною стадією серії таких мікропроектів, а предметною галуззю всіх робіт об'єкти автоматизації галузі залізничного транспорту.

Навчання технологій Industry 4.0, безумовно, повинно спиратися на відповідну лабораторну базу. Наприклад, для отримання навичок створення IоT мінімальний набір обладнання в лабораторії включає: сенсори, актуатори, мікроконтролери i мікропроцесори; розширені вбудовані системи; середовища розробки програмного забезпечення та доступ до хмарної інфраструктури. Сьогодні студенти в лабораторіях «розумних систем» та «Інтернету речей» кафедри інформаційних технологій УкрДУЗТ використовують Raspberry Pi, Arduino та ESP для розробки додатків, які мають декілька типів зовнішніх інтерфейсів введення/виведення. Спектр розширених вбудованих систем представлений великим набором різного роду інтелектуальних сенсорів, мобільних платформ, роботів, дронів і інших рухомих моделей, які мають власні мікроконтролери, сенсори. Організація лабораторного практикуму має бути суттєво змінена. Кожен студент повинен отримати повноцінний інструментарій «ІоТ в коробці». Сучасний рівень цін на зазначені компоненти лабораторного практикуму робить доступним для університетів такий підхід. Причому - це апаратний ресурс неодноразового використання, проте оборотність його не менше чотирьох років. Зараз активно розробляються апаратні i програмні платформи, поширювані на принципах Open Source, що дозволяє частково скоротити витрати на лабораторну базу. Переваги Open Source виражаються в простоті переконфігурування електронних компонентів і можливості використання стандартних мов програмування (C/C++, C\#, Python або Java) для розробки програмного забезпечення ІоТ-пристроїв.

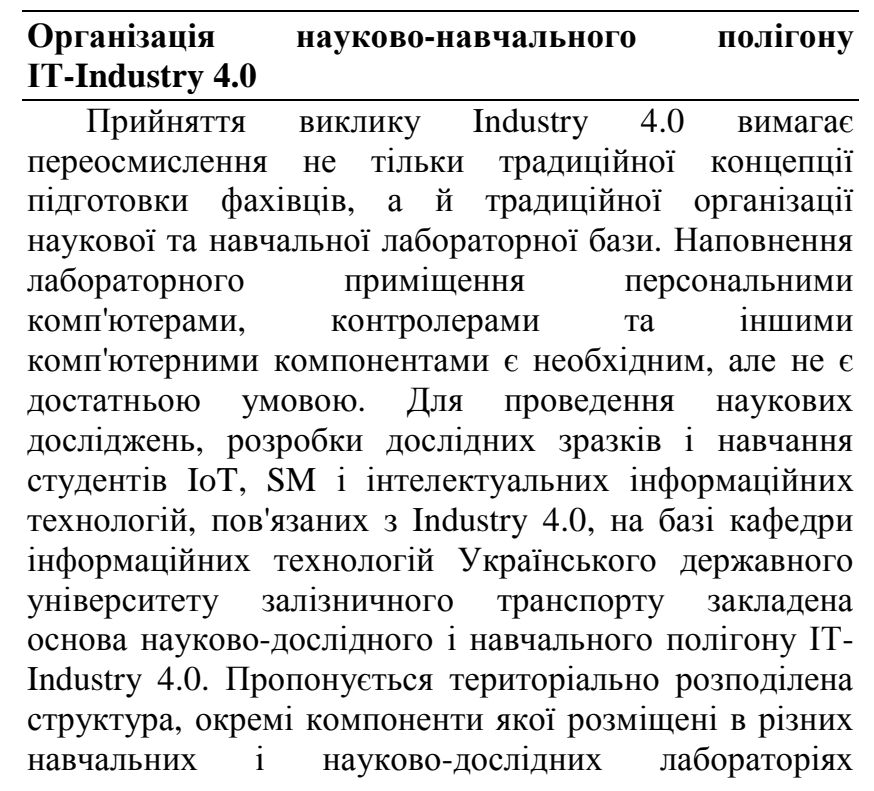

університету. Архітектура є відкритою для подальшого включення фрагментів діючої інфраструктури галузі залізничного транспорту, рухомих одиниць. Відкритість і масштабованість досягається завдяки використанню інформаційних технологій, що підтримують Industry 4.0. На першому етапі створення полігону об'єктами дослідження (ОД), що рухаються, є моделі SM, представлені інтелектуальними колісними роботами, дронами і іншими пристроями, а стаціонарні ОД - моделями фрагментів інфраструктури залізниці 3 реалізацією IoT. Апаратно-програмний комплекс полігону (мікропроцесори, мікроконтролери 3 модулями wi-fi, наприклад, ESP8266, інтелектуальні сенсори і актуатори) підтримує технологію М2M. Роботи оснащені різними інтелектуальними сенсорними системами для виконання певних функцій. Серед них $\epsilon$ робот-розвідник пожежонебезпечних ситуацій, що обробляє інформацію від сенсорів вологості, температури, задимленості і освітленості; робот-спостерігач, який слідкує за змінами будь-яких параметрів оточення (здійснює відеоспостереження за допомогою відеокамери Raspberry Pi 5MP Camera, реєструє рух за допомогою інфрачервоного i ультразвукового датчиків, контролює зміни освітленості, звуку та ін.).

Таким чином, на першому етапі полігон являє собою мережу з SM (автономних мобільних роботів, які задовольняють вимоги інтелектуальних машин [18]) i IoT (моделі інфраструктури залізниці: вагон, переїзд, ділянки магістралі), які взаємодіють один 3 одним по протоколу СоАР [19] (одна із технологій M2M), мають доступ до хмарних даних i місцезнаходження окремих SM. Передбачено поетапне підключення реальних фрагментів рухомого складу та інфраструктури залізниці для тестування рішень, без втручання в основний виробничий процес.

На думку багатьох ІT-фахівців, сьогодні прийшов час створювати великомасштабні інфраструктури для досліджень i викладання широкого кола тем, пов'язаних концепцією Industry 4.0.

\section{Висновки}

Стратегічний план підготовки кадрів нового покоління для залізничної галузі у галузі IT повинен враховувати досвід підготовки ІТ-фахівців у розвинених країнах світу, стратегії розвитку залізничного транспорту як України, так і країн Євросоюзу.

Головні завдання, які необхідні для успішної реалізації цього плану, передбачають:

1. Участь в програмах підтримки університетів 3 боку провідних IT-компаній світу (Microsoft, IBM, Cisco, Amazon, Siemens) 3 метою використання сучасного ліцензійного програмного забезпечення для підготовки IT-фахівців i отримання навчальних матеріалів, зокрема по IoT та SM [20,21]. 


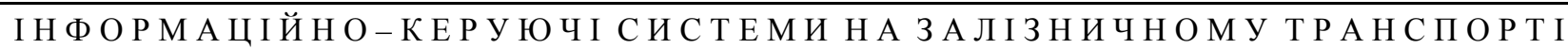

2. Проходження курсів (з отриманням сертифікатів) 3 ІТ-технологій в провідних центрах online-підготовки [22-24] як для викладачів, так і для студентів. Обгрунтування потреби в безкоштовній формі навчання і сертифікації при реєстрації дозволяє отримати знання i українським студентам, i викладачам.

3. Забезпечення науково-навчальних полігонів IT-Industry 4.0 доступними мікропроцесорами i мікроконтролерами 3 наборами сенсорів і актуаторів для проведення досліджень магістрантами i аспірантами та лабораторних занять бакалаврів.

4. Можливість корпоративного доступу до ресурсів суспільства IEEE, як найбільш інформативного центру сучасних інновацій у галузі IT [25].

5. Участь в Хартії «Індустрія 4.0 в Україні» 3 метою підготовки ІТ-фахівців відповідно до вимог високотехнологічних секторів економіки України [14].

6. Участь в бізнес-форумах по Industry 4.03 метою залучення молоді до конкурсів по ІоТ [26].

7. Доступність безпровідних мереж високої якості на території університету, що дозволить побудувати інфраструктуру для студентських проектів по IoT.

8. Стимулювання роботи студентів 3 використанням ресурсів GitHub [27], як джерела проектів у галузі IT і платформи для розміщення колективних проектів.

\section{Список використаних джерел}

1. Промышленная революция 4.0. На пороге новой эпохи. URL: http://chp.com.ua/all-news/item/46476promyshlennaya-revolyutsiya-4-0-na-poroge-novojepokhi (Дата обращения: 14.08.2017).

2. An Executive's Guide to Industry 4.0, Smart Factories and Beyond. URL: http://www.ioti.com/industrial-iotiiot/executive-s-guide-industry-40-smart-factoriesand-beyond (Last accessed: 14.08.2017).

3. "Industry 4.0 Survey: Building the Digital Enterprise," by Gary Mintchell, The Manufacturing Connection, September 16, 2016. URL: http://themanufacturingconnection.com/2016/09/indus try-4-0-survey-building-digital-enterprise/ (Last accessed: 14.08.2017).

4. 12 Highlights from Siemens Massive Hannover Messe Booth. URL: http://www.ioti.com/iot-trends-andanalysis/12-highlights-siemens-massive-hannovermesse-booth (Last accessed: 14.08.2017).

5. Microsoft Opens Its First European Lab for Internet of Things. URL: http://www.ioti.com/security/newversion-mirai-botnet-emerges?NL=IOT001UBER\&Issue=IOT-001UBER 20170330_IOT001UBER 743\&sfvc4enews $=42 \& \mathrm{cl}=$ article 4 b\&ut $\underline{m}$ rid=CPG03000003510982\&utm_campaign $=18092$ \&utm_medium $=$ email\&elq2 $=505 \mathrm{e} 563 \mathrm{a} 1 \mathrm{~b} 4246 \mathrm{bfb} 533$ 37910454e703 (Last accessed: 14.08.2017).

6. SAP Leonardo: инвестируем в Интернет вещей 2 миллиарда евро.

URL: https://www.sap.com/cis/trends/internet-of-things.html (Дата обращения: 14.08.2017).

7. China's 'smart cities' to number 500 before end of 2017.

URL:

http://www.chinadaily.com.cn/china/2017-

04/21/content_29024793.htm (Last accessed: 14.08.2017).

8. ДОПОВІДЬ про стан інформатизації та розвиток інформаційного суспільства в Україні за 2013 рік, 123

c.

URL:

http://www.dknii.gov.ua/sites/default/files/stan_infor matyzacii_20132.pdf (Дата звернення: 14.08.2017).

9. ПОСТАНОВА Верховної Ради України «Про Рекомендації парламентських слухань на тему: «Реформи галузі інформаційно-комунікаційних технологій та розвиток інформаційного простору України» (Відомості Верховної Ради (ВВР), 2016, № 17, ст.191). URL: http://zakon3.rada.gov.ua/laws/show/1073-19 (Дата звернення: 14.08.2017).

10. A Railway Strategy for CAREC, 2017-2030 - Asian Development Bank. URL: https://www.adb.org/sites/default/files/-institutionaldocument/227176/carec-railway-strategy-20172030.pdf (Last accessed: 14.08.2017).

11. Rail Technical Strategy Capability Delivery Plan. URL: https://www.rssb.co.uk/rts/Documents/2017-0127-rail-technical-strategy-capability-delivery-planbrochure.pdf (Last accessed: 14.08.2017).

12. Індустрія 4.0 в Україні. URL: http://industry4-0ukraine.com.ua/ (Дата звернення: 14.08.2017).

13. Рух «Індустрія 4.0 в Україні» об'єднує гравців IT та ACY TП. URL: http://appau.org.ua/ru/Ruh_Industry_4-

0_v_Ukraini_obednue_gravciv_\%D0\%86\%D0\%A2_t a_ASUTP (Дата звернення: 14.08.2017).

14. Хартія «Індустрія 4.0 в Україні». URL: http://appau.org.ua/ru/Hartiya_Industriya 40 in Ukraine (Дата звернення: 14.08.2017).

15. Resnick M. et al., Scratch: Programming for All, Communications of the ACM, 2009, vol. 52, no. 11, pp. 60-67. URL: https://web.media.mit.edu/ mres/papers/ScratchCACM-final.pdf (Last accessed: 14.08.2017).

16. «Майкрософт Украина» поддержала обучение школьников основам IoT. URL: http://ko.com.ua/majkrosoft_ukraina_podderzhala_ob uchenie_shkolnikov_osnovam_iot_117893 (Дата обращения: 14.08.2017).

17. NMC Horizon Report 2017 Higher Education Edition. URL: http://cdn.nmc.org/media/2017-nmc-horizonreport-he-EN.pdf (Last accessed: 14.08.2017). 
18. Каргин А. А. Введение в интеллектуальные машины. Книга 1. Интеллектуальные регуляторы [Текст] / А. А. Каргин. - Донецк: Норд-Пресс, ДонНУ, 2010. $-526 \mathrm{c}$.

19. Constrained Application Protocol. From Wikipedia.

URL: https://en.wikipedia.org/wiki/Constrained_Application_Pro tocol (Last accessed: 14.08.2017).

20. Welcome to IBM Global University Programs. URL: http://www.research.ibm.com/university/ (Last accessed: 14.08.2017).

21. Take Cisco Connected Rail. URL: http://www.cisco.com/c/en/us/solutions/industries/transpor tation/rail.html (Last accessed: 14.08.2017).

22. The world's best courses, online. URL: https://www.coursera.org/ (Last accessed: 14.08.2017).

23. Learn from Stanford Online. For anyone, anywhere, anytime. URL: https://lagunita.stanford.edu/ (Last accessed: 14.08.2017).

24. Free Online Courses. Advance Your Career. Improve Your Life. URL: https://www.edx.org/ (Last accessed: 14.08.2017)

25. Institute of Electrical and Electronics Engineers. URL: https://www.ieee.org/index.html (Last accessed: 14.08.2017).

26. CIS Events Group. Your new marketing wave... URL: https://ciseventsgroup.com/ (Last accessed: 14.08.2017).

27. Built for developers. URL: https://github.com/ (Last accessed: 14.08.2017).

Панченко С.В., Каргин А.А., Петренко Т.Г. Научноучебный полигон IT-Industry 4.0: стратегические задачи подготовки IT-специалистов для отрасли железнодорожного транспорта. Одним из главных вопросов, связанных с индустриальной революцией 4.0, является подготовка специалистов нового поколения в области информационных технологий. Отрасль железнодорожного транспорта является одним из лидеров внедрения концепций Industry 4.0. В планах стратегического развития железнодорожной отрасли развитых стран мира предполагается широкое применение информационных технологий, основанных на моделях искусственного интеллекта, для создания индустриальных «Интернет-вещей», «умных машин» и других высокоинтеллектуальных систем. Разработка и обслуживание систем такого класса требует ИТспециалистов. Путям решения проблемы подготовки ИТ-специалистов для железнодорожной отрасли, которые востребованы Industry 4.0, посвящена статья.

Ключевые слова: Industry 4.0, умные машины, Интернет вещей, интеллектуальные информационные технологии, подготовка специалистов.
Panchenko S.V., Kargin A.A., Petrenko T.G. The scientific and training polygon IT-Industry 4.0: strategic tasks for the training of IT specialists for the railway transport industry. One of the main issues related to the industrial revolution 4.0 is the training of specialists of a new generation in the field of information technology. The railway transport industry is one of the leaders in the implementation of Industry 4.0 concepts. In the plans for the strategic development of the railway industry of the developed countries, it is expected that the use of information technologies based on artificial intelligence models will be widely used to create industrial Internet items, smart machines and other highly intelligent systems. The development and maintenance of systems of this class requires IT professionals. Ways to solve the problem of training IT professionals for the railway industry, in demanded Industry 4.0, are discussed in the article.

Keywords: Industry 4.0, smart machines, the Internet of things, artificial intelligence information technologies, training of specialists.

Надійшла 16.08.2017 p.

Панченко Сергій Володимирович, доктор технічних наук, професор, ректор, Украӥнський державний університет залізничного транспорту, Харків, Україна. ORCID ID: 0000-0002-7626-9933. E-mail: info@kart.edu.ua.

Каргін Анатолій олексійович, доктор технічних наук, професор, завідувач кафедри, Украӥнський державний університет залізничного транспорту, Харків, Україна. E-mail: kargin@kart.edu.иа.

Петренкотетяна Григорівна, кандидат технічних наук, доиент, дочент кафедри, Украйнський державний університет залізничного транспорту, Харків, Украӥна. E-mail: petrenko_tg@kart.edu.ua.

Panchenko S.V., rector, Doctor of Techn. Sciences, professor, Ukrainian State University of Railway Transport, Kharkiv, Ukraine. ORCID ID: 0000-00027626-9933.E-mail:info@kart.edu.ua.

Kargin A.A., head of the department, Doctor of Techn. Sciences, professor, Ukrainian State University of Railway Transport, Kharkiv, Ukraine. E-mail: kargin@kart.edu.ua. Petrenko T.G., associate professor, Kandidat of Techn. Sciences, associate professor, Ukrainian State University of Railway Transport, Kharkiv, Ukraine. E-mail: petrenko_tg@kart.edu.ua. 